\title{
PENGARUH KETELADANAN GURU MADRASAH IBTIDAIYAH \\ TERHADAP PERILAKU DISIPLIN PESERTA DIDIK DI MI NEGERI MANIS KIDUL KECAMATAN JALAKSANA KABUPATEN KUNINGAN
}

\section{Oleh:}

\author{
Dr. H. Latifah, M. Ag. \\ Ida Nuraida
}

\section{A. Pendahuluan}

Di dunia pendidikan banyak elemen yang terlibat didalamnya, salah satunya adalah guru atau pendidik."Pendidikan merupakan suatu aktivitas yang mengembangkan seluruh aspek kepribadian manusia yang berjalan seumur hidup. Guru mempunyai peran yang sangat penting dalam perkembangan peserta didik untuk mewujudkan cita-citanya. Guru pula yang memberikan dorongan agar peserta didik berlaku sesuai dengan aturan yang berlaku. Dalam hal ini guru-pun memberikan keteladan dan di contohkan dalam kehidupan sehari-hari agar peserta didik dapat mengikutinya (Hasan Basri 2009 : 21).

Bagi seorang guru, menjadi teladan yang baik bagi anak didiknya adalah mutlak dan tidak bisa di tinggalkan karena itulah jalan satu-satunya untuk menciptakan anak didik yang unggul dan handal. Memang masa depan anak didik tergantung di pundak mereka masing-masing, namun sebagai guru merupakan kunci pembuka pintu ke masa depan, sebagai lentera yang menerangi jalan ke masa depan, adalah tongkat yang akan menuntun pada setiap titian menuju masa depan, dan lautan kasih sayang berlabuh dan berlayarnya perahu-perahu menuju dermaga keberhasilan.(Gustaf Ashirint, $2010: 34)$.

pada kenyataannya guru sudah memberikan contoh seperti perkataan, perbuatan dan tingkah laku teladan yang baik, akan tetapi peserta didik masih saja tidak dapat mencontoh atau meneladaninya. Siswa cenderung berperilaku sesuai dengan keinginannya tidak mematuhi peraturan yang berlaku disekolah.

Jika kondisi seperti ini terus berlangsung, pembelajaran akan menjadi tidak kondusif dan tujuan sekolah tidak akan terpenuhi terutama 
masalah kedisiplinan. Oleh sebab itu sebagai guru hendaknya melakukan perbaikan dan memberikan teladan yang baik agar dapat memberikan contoh serta pengaruh yang baik terhadap peserta didik sehingga perilaku disiplin peserta didik dapat di terapkan di sekolah.

Permasalahan yang dihadapi oleh MI Negeri Maniskidul Jalaksana yaitu kurangnya kedisiplinan peserta didik. Masalah tersebut di karenakan rendahnya sikap rasa tanggung jawab yang tertanam dalam diri peserta didik. Hal ini bisa terjadi karena dua alasan. Alasan yang pertama yaitu timbul dari diri pribadinya seperti membuang sampah sembarangan, tutur kata dan sopan santun kurang baik, berpakaian tidak rapih, mempunyai kebiasaan berperilaku tidak disilin dan enggan untuk mematuhi peraturan yang ada di sekolah. Alsan yang kedua di sebabkan karena kondisi di lingkungan sekolah dan lingkungan kelas yang kurang kondusif.

Oleh karena itu,berdasarkan fenomena di atas, maka di dapat pertanyaan penelitian berikut:

1) Bagaimana Keteladanan guru di MI ManiskidulKecamatan Jalaksana Kabupaten Kuningan?

2) Bagaimana Perilaku disiplin peserta didik di MI Maniskidul Kecamatan Jalaksana Kabupaten Kuningan?

3) Sejauhmana Pengaruh keteladanan guru MI terhadap perilaku disiplin peserta didik di MI Manis Kidul Kecamatan Jalaksana Kabupaten Kuningan?

\section{B. Kerangka Pemikiran}

Keteladanan merupakan pigur yang baik. Tujuannya agar dapat membentuk perilaku peserta didik dengan baik. Fungsi keteladanan dalam proses belajar-mengajar bukan merupakan fungsi tambahan tetapi mempunyai fungsi tesendiri keberhasilnya sangat bergantung pada kualitas, kesungguhan realisasi karateristik pendidik yang diteladani misalnya guru memberikan contoh dalam berpakaian guru selalu rapi, dalam penampilan guru juga rapi, tutur kata yang di sampaikan selalu baik, keikhlasannya dalam mengajar. 
Sebagai pemimpin, guru sejati berada di garis depan untuk memberikan contoh keteladanan dan panutan bagi anak didiknya. Seorang guru sejati akan memimpin anak didiknya dengan penuh keselarasan antara ucapan dan tindakan. Ucapan adalah fungsi komunikasi dalam menyampaikan pemahaman, dan tindakan adalah wujud nyata dari pelaksanaan kata-kata yang secara bersama-sama antara guru dan murid di wujudkan secara out put, hasil karya bentuk-bentuk keberhasilan maupun prestasi lainnya.di sinilah sosok guru sebaggai pemimpin di depan maupun menjadi sumber belajar dan fasilitator serta mampu meneladankan keberhasilan secara nyata kepada siswanya (Gustaf Ashirint, 2010 : 26).

Disiplin adalah suatu tata tertib yang dapat mengatur tatanan kehidupan pribadi dan kelompok. Kedisiplinan mempunyai peranan penting dalam mencapai tujuan pendidikan. Berkualitas atau tidaknya belajar siswa sangat dipengaruhi oleh paktor yang paling pokok yaitu kedispilan, disamping paktor lingkungan, baik keluarga, sekolah, kedisiplinan setra bakat siswa itu sendiri.

Berpijak pada definisi tersebut, diketahui bahwa disiplin belajar sebenarnya suatu bentuk kesadaran diri untuk mengendalikan dirinya. Dalam hal ini, disiplin belajar berfungsi sebagai pengendali diri yang berada pada diri orang tersebut sehingga belajar akan penuh kesadaran, tanpa paksaan dan penuh sukacita/bersyukur. Spesifikya yaitu orang yang berdisiplin belajar akan belajar tanpa paksaan dan sadar untuk belajar dan belajar. Memang untuk mengaplikasikan pengertian disiplin belajar ini tidaklah mudah tetapi tidak berarti tidak mungkin berhasil. Karena untuk mampu disiplin dalam belajar memerlukan suatu perenungan untuk terus bertanya pada diri mengapa saya harus belajar hingga orang tersebut memperoleh suatu alasan yang mendalam dan memuat spiritualitas, emosi dan kognitif mengapa harus belajar.

Dalam kaitannya dengan proses belajar-mengajar di sekolah, keteladanan guru sangat erat hubungannya dengan kedisiplinan peserta didik karena keteladanan merupakan contoh yang baik yang dapat memberikan pengaruh positif.Perencanaan penelitian ini akan menggunakan angket 
sebagai alat ukur. Angket pertama di gunakan untuk mengetahui keteladan guru dan angket yang ke dua untuk mengetahui kedisiplinan peserta didik.

Gambar 1.1 Diagram Kerangka Berfikir

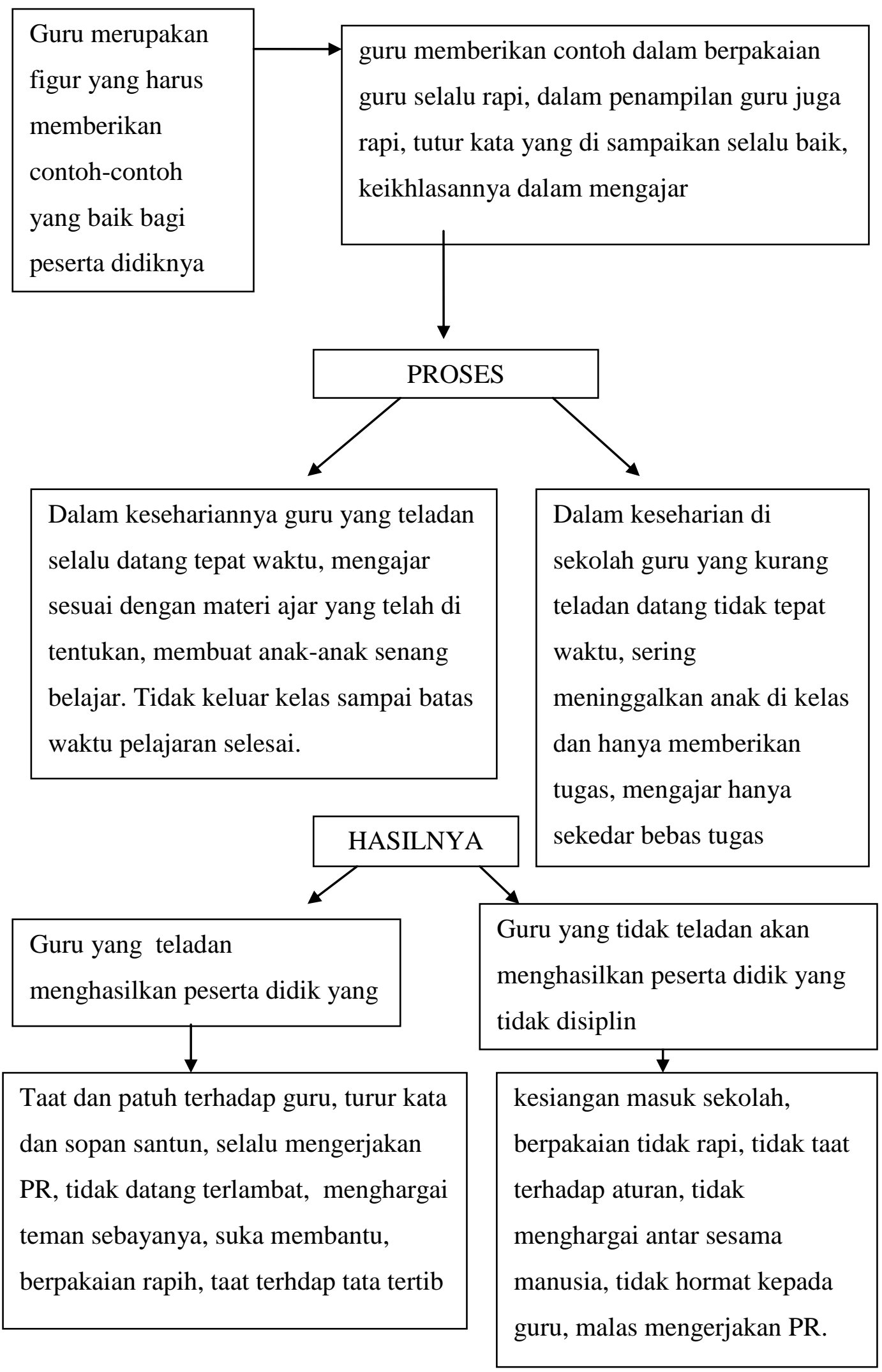


Teladan artinya sesuatu (perbuatan) yang dapat di tiru (Kamus Bahasa Indonesia, PN. Balai Pustaka, 1978 : 1038), Guru yang artinya orang yang kerjanya mengajar (Kamus Bahasa Indonesia,PN.Balai Pustaka,1975 : 334)

Guru sebagai uswah atau teladan harus memiliki modal dan sifat-sifat tertentu, diantaranya: Pertama, Guru harus meneladani Rasulullah Saw sebagai teladan seluruh alam. Sebagaimana termaktub dalam Al-Quran surat Al-Ahzab ayat 21 yang artinya: "Sesungguhnya telah ada pada (diri) Rasulullah itu suri teladan yang baik bagimu (yaitu) bagi orang yang mengharap (rahmat) Allah dan (kedatangan) hari kiamat dan dia banyak menyebut Allah".

Kedua, guru harus benar-benar memahami prinsip-prinsip keteladanan. Mulailah dengan ibda' binafsih, yaitu dari diri sendiri. Dengan demikian guru tidak hanya pandai bicara dan mengkritik tanpa pernah menilai dirinya sendiri. Bercermin pada filosofi "gayung mandi", dalam mendidik karakter guru jangan seperti gayung mandi. Gayung digunakan untuk mandi bertujuan membersihkan, tapi ia sendiri tidak pernah mandi atau membersihkan dirinya sendiri.Artinya guru harus mempraktikkannya terlebih dahulu sebelum mengajarkan karakter kepada peserta didiknya.

Ketiga,guru harus mengetahui tahapan mendidik karakter. Sekurangkurangnya melalui tiga tahapan pembelajaran yang penulis istilahkan dengan 3P yaitu: pemikiran, perasaan dan perbuatan. Tahapan pertama pemikiran; merupakan tahap memberikan pengetahuan tentang karakter. Pada tahapan ini guru berusaha mengisi akal, rasio dan logika siswa sehingga siswa mampu membedakan karakter positif (baik) dengan karakter negatif (tidak baik). Siswa mampu memahami secara logis dan rasional pentingnya karakter positif dan bahaya yang ditimbulkan karakter negatif.

Pada dasarnya perubahan perilaku yang dapat ditunjukan oleh peserta didik harus dipengaruhi oleh latar belakang pendidikan dan pengalaman yang dimiliki oleh seorang guru. Atau dengan perkataan lain, guru mempunyai pengaruh terhadap perubahan perilaku peserta didik. Untuk itulah guru harus dapat menjadi contoh (suri teladan) bagi peserta didik, karena pada dasarnya guru adalah representasi dari sekelompok orang pada suatu komunitas atau masyarakat yang diharapkan dapat menjadi teladan, yang dapat digugu dan ditiru.

Bagi seorang guru menjadi teladan bagi anak didiknya adalah mutlak dan tidak bisa di tinggalkan. Bahkan sebelum anda menjadi guru, keteladanan itu harus sudah tertanam dalam niat dan hati anda. Karena itulah jalan satusatunya untuk bisa menciptakan anak didik yang unggul dan handal (Gustaf Asyirint 2010:34). 


\section{Pengertian Guru}

Secara normatif, dalam UU No. 14 tahun 2005 bab I umum, Pasal I ayat I di sebutkan bahwa guru adalah pendidik profesional dengan tugas utama mendidik, mengajar, membimbing, mengarahkan, melatih, menilai dan mengevaluasi peserta didik pada pendidikan anak usia dini jalur pendidikan formal, pendidikan dasar dan pendidikan menengah (Dedi Permadi dan Daeng Arifin, 2010 :176).

Guru adalah titik pokok dari suatu kurikulum. Berkat usaha guru, timbul kegairahan belajar siswa. Karena itu, guru harus memiliki bermacam-macam tingkat keterampilan, ungkin karena bakatnya baik sebagai guru atau karena persiapannya yang lebih baik (Anas Salahudin, 2010:190).

Pendidik adalah sebagai peran pembimbing dalam melaksanakan proses belajar mengajar. Menyediakan kondisi-kondisi yang memungkinkan siswa merasa aman dan berkeyakinan bahwa kecakapan dan prestasi yang dicapai mendapat penghargaan dan perhatian sehingga dapat meningkatkan motivasi berprestasi siswa(Ahmadi 1977: 109).

Jadi pengertian guru berdasarkan teori di atas adalah orang yang bertanggung jawab atas perkembangan peserta didik terutama dari hal pendidikan dan perkembangan peserta didik. Baik dari ranah kognitif, apektif, dan psikomotorik. Guru juga orang yang bertanggung jawab dalam membantu dan memberi pertolongan kepada peserta didik agar dapat terpenuhi ketiga asfek tersebut.

\section{Perilaku Disiplin Peserta Didik}

\section{a. Pengertian Disiplin}

Sikap atau perilaku merupakan cerminan jiwa seseorang. Jika perasaan seseorang terhadap sesuatu adalah positif maka akan terpancar pula perilaku positif bersangkutan menyikapi sesuatu yang di hadapinya itu. Dan sebaliknya, jika perasaan sedang tidak nyaman maka yang tercermin adalah wajah yang keruh, semngat kerja menurun hari yang indah dapat berubah menjadi hari yang membosankan (Inge Hutagalung 2007:52)

Dari pengertian tersebut perilaku individu dapat diartikan sebagai suatu sikap atau tindakan serta segala sesuatu yang dilakukan manusia baik yang dilakukan dalam bekerja maupun diluar pekerjaan seperti berbicara, bertukar pendapat, berjalan dan sebagainya.Setiap individu mempunyai karakteristik yang berbeda, 
sehingga setiap manusia mempunyai keunikan-keunikan tersendiri. Oleh sebab itu antara individu yang satu dengan yang lain pasti mempunyai perbedaan-perbedaan.

Dari pengertian diatas dapat kita simpulkan bahwa disiplin mengacu pada pola tingkah laku dengan ciri-ciri sebagai berikut:

1) Adanya hasrat yang kuat untuk melaksanakan sepenuhnya apa yang sudah menjadi norma, etik, dan kaidah yang berlaku dalam masyarakat.

2) Adanya prilaku yang dikendalikan.

3) Adanya ketaatan

\section{b. Indikator Perilaku Disiplin}

Pada dasarnya perilaku disiplin harus merupakan pendidikan yang sangat penting. Indikator disiplin diantaranya:

1) Disiplin dalam Menggunakan Waktu Maksudnya bisa menggunakan dan membagi waktu dengan baik. Karena waktu amat berharga dan salah satu kunci kesuksesan adalah dengan bisa menggunakan waktu dengan baik

2) Disiplin dalam Beribadah Maksudnya ialahsenantiasa beribadah dengan peraturan-peratuaran yang terdapat didalamnya. Kedisiplinan dalam beribadah amat dibutuhkan, Allah SWT senantiasa menganjurkan manusiauntuk Disiplin, sebagai contoh firman Allah SWT.Artinya:“ Maka kecelakaanlah bagaiorangorang yang salta, (situ) orang orang yang lalaidari shalatnya"(QS.Al-Ma`un:4-5)

3) Disiplin dalam Masyarakat

\section{c. Faktor-Faktor yang Mempengaruhi Sikap Kurang Disiplin:}

1) Sekolah kurang menerapkan disiplin.

Sekolah yang kurang menerapkan disiplin, maka siswa biasanya kurang bertanggung jawab karena siswa menganggap tidak melaksanakan tugas pun di sekolah tidak dikenakan sanksi, tidak dimarahi guru. 
2) Teman bergaul.

Anak yang bergaul dengan anak yang kurang baik perilakunya akan berpengaruh terhadap anak yang diajaknya berintraksi sehari hari

3) Cara hidup di lingkungan anak tinggal.

Anak yang tinggal di lingkungan hidupnya kurang baik, maka anak akan cendrung bersikap dan berperilaku kurang baik pula.

4) Sikap orang tua.

Anak yang dimanjakan oleh orang tuanya akan cendrung kurang bertanggung jawab dan takut menghadapi tantangan dan kesulitan kesulitan, begutu pula seballiknya anak yang sikap orang tuanya otoriter, maka anak akan menjadi penakut dan tidak berani mengambil keputusan dalam bertindak.

5) Keluarga yang tidak harmonis.

Anak yang tumbuh dikeluarga yang kurang harmonis (home broken) biasanya akan selalu mengganggu teman dan sikapnya kurang disiplin.

6) Latar belakang kebiasan dan budaya.

Budaya dan tingkat pendidikan orang tuanya akan berpengar terhadap sikap dan perilaku anak. Anak yang hidup dikeluarga yang baik dan tingkat pendidikan orang tunya bagus maka anak akan cendrung berperilaku yang baik pula.

\section{Metode Peneltian}

\section{Tempat dan Waktu Penelitian}

a. Tempat Penelitian

Penelitian ini di lakukan di Madrasah Ibtidaiyah Negeri Maniskidul Kecamatan Jalaksana Kabupaten Kuningan

b. Waktu Penelitian

Waktu yang di gnakan penulis dalam penelitian ini dilakukan selama 2 bulan di mulai dari tanggal 1 mei sampai dengan 30 juni 2014. 


\section{Deskripsi Lokasi Penelitian}

Madrasah Ibtidaiyah Negeri Maniskidul Kecamatan Jalaksana Kabupaten Kuningan di dirikan pada 25 oktober 1995 memenuhi kebutuhan masyarakat akan lembaga pendidikan Madrasah Ibtidaiyah. Pendiriannya merupakan suatu terobosan dalam dunia pendidikan bagi masyarakat Desa Manis Kidul Kecamatan Jalaksana Kabupaten Kuningan.

\section{Metode Penelitian}

\section{a. Variabel}

Mengacu dari tinjauan teori diatas, variabel-variabel dalam penelitian ini dapat didefinisikan sebagai berikut:

1) Keteladanan guru Madrasah Ibtidaiyah sebagai variabel $X$ adalah kemampuan seorang guru dalam membentuk peserta didik, dan memberi contoh yang baik agar kelak peserta didik tumbuh sebagai anak yang pintar dan berakhlakul karimah.

2) Perilaku Kedisiplinan pesta didik sebagai variabel $Y$ adalah dorongan internal dan eksternal pada peserta didik sehingga menjadi pribadi yang baik.

\section{b. Desain Penelitian}

Desain penelitian adalah sebuah istilah yang diambil dari kata "design" yaitu berarti perancangan atau rancangan. Desain penelitian adalah semua proses yang di perlukan dalam perencanaan dalam pelaksanaan penelitian. (Nurhalimah, 2011:53)

Pada praktik penelitian juga di perlukan adanya desain penelitian yang sesuai dan seimbang dengan keadaan yangdi kerjakan. Adapun desain yang dipakai dalam penelitian ini adalah:

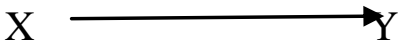

Keterangan:

$\mathrm{X}=$ Keteladanan Guru

$\mathrm{Y} \quad=$ Kedisiplinan Peserta didik

$\longrightarrow \quad=$ Hubungan yang menunjukan pengaruh 


\section{c. Populasi}

Populasi menurut Mahmud (2011 : 154) adalah totalitas dari semua objek atau individu yang memiliki karakteristik tertentu, jelas dan lengkap yang akan di teliti.

Pengertian lain tentang populasi adalah keseluruhan objek penelitian. (Suharsimi Arikunto, 2012:173).Populasi yang di gunakan adalah siwa dari mulai kelas 1 - 6.MI Negeri Maniskidul Kecamatan Jalaksana Kabupaten Kuningan.

\section{d. Sampel}

Sampel adalah sebagian anggota populasi yang di ambildengan menggunakan teknik tertentu yang di sebut dengan teknik sampling. (Suharsimi Arrikunto, 2011:147)

Teknik sampling yang di gunakan yaitu Cluster Sampling. Cluster Sampling adalah teknik pengambilan sampel dimana pemilihannya mengacu pada kelompok bukan padaindividu. Sampel yang digunakan adalah kelas V MI negeri Maniskidul Kecamatan Jalaksana Kabupaten Kuningan. dengan jumlah 40 siswa.

\section{e. Teknik Pengumpulan Data}

Teknik pengumpulan data yang di lakukan oleh peneliti di MI Manis Kidul Kecamatan Jalaksana Kabupaten Kuningan adalah melalui penyebaran angket, dan observasi. Angket di gunakan untuk mengukur respon peserta didik mengenai pengaruh keteladanan guru dan perilaku disiplin peserta didik. Sedangkan obeservasi di gunakan untuk mengetahui kesesuaian pelaksanaan tindakan dengan rencana tindakan yang telah disusun sebelumnya.

\section{f. Instrumen Penelitian}

Instrumen adalah alat untuk mengumpulkan data mengenai variabel-variabel peneitian. (TotoSyatori Nasehuddien, 2011:92)

Adapun instrumen yang di gunakan dalam penelitian ini adalah angket mengenai keteladanan guru madrasah ibtidaiyah dan 
angket perilaku disiplin peserta didik. Angket di gunakan untuk mengukur respon peserta didik mengenai pengaruh keteladanan guru terhadap perilaku disiplin peserta didik di MI Maniskidul kecamatan Jalaksana Kabupaten Kuningan

\section{g. Teknik Analisis Instrumen}

Sebelum data angket di gunakan instrumen tersebut terlebih dahulu di uji cobakan. Uji coba ini diimaksudkan untuk mengetahui gambaran tentang terpenuhi atau tidaknya syarat-syarat instrumen sebagai alat pengumpul data yang baik, sehingga instrumen ini dapat di gunakan.

\section{h. Teknik Analisis Data}

Setelah data terkumpul dari hasil pengumpulan data, penı selanjutnya menganalisis data untuk mencari korelasi antara keteladanan guru dengan kedisiplinan peserta didik.

\section{E. Hasil dan Pembahasan}

\section{Deskripsi Data Hasil Penelitian}

\section{a. Hasil Analisis Angket Keteladanan Guru Madrasah Ibtidaiyah}

Angket dalam penelitian ini digunakan untuk mengetahui keteladanan guru Madrasah Ibtidaiyah di Madrasah Ibtidaiyah Negeri Maniskidul Kecamatan Jalaksana Kabupaten Kuningan. Guru teladan adalah guru yang mampu menjalankan perannya sebagai guru dan pendidik dengan baik dan benar. Guru yang teladan adalah panutan bagi semua siswa. Sebagai gambaran dari keteladanan guru penulis menyebarkan Angket, angket itu diberikan pada siswa setelah selsai pembelajaran.Angket ini berisi 15 pernyataan. Kemudian angket di sebar kepada seluruh siswa kelas V yang berjumlah 40 siswa. Siswa diminta untuk mengisinya dengan menentukan salah satu pilihan (sangat setuju, setuju, tidak setuju, sangat tidak setuju) yang sesuai dengan sikap yang dimilikinya. 


\section{b. Hasil Analisis Angket Perilaku Disiplin Peserta Didik}

Angket dalam penelitian ini digunakan untuk mengetahui perilaku disiplin peserta didik di Madrasah Ibtidaiyah Negeri Maniskidul Kecamatan Jalaksana Kabupaten Kuningan.perilaku disiplin peserta didik adalah faktor penting yang harus di cermati karena dengan perilaku disiplin salah satunya akan meningkatkan kualitas Madrasah mulai dari tepat waktunya masuk sekolah, kebersihannya, dan ketertiban di lingkungan sekolah. Perilaku disiplin juga tidak lepas dari guru sebagai pendidik. Sebagai gambaran perilaku disiplin peserta didik, penulis menyebarkan angket diberikan pada siswa setelah selsai pembelajaran.Angket ini berisi 15 pernyataan, angket di sebar kepada seluruh siswa kelas V yang berjumlah 40 siswa. Siswa diminta untuk mengisinya dengan menentukan salah satu pilihan (sangat setuju, setuju, tidak setuju, sangat tidak setuju) yang sesuai dengan sikap yang dimilikinya.

\section{Pembahasan Hasil Penelitian}

\section{a. Keteladanan Guru}

Keteladanan merupakan salah satu yang terpenting yang harus di miliki oleh oleh seorang guru karena melalui keteladanan dapat menciptakan generasi penerus bangsa yang mempunyai perilaku yang baik. Berdasarkan hasil angket penelitian keteladanan guru di kelas V MI Negeri Maniskidul Kecamatan Jalaksana kabupaten Kuningan dengan jumlah 40 siswa di perolah menunjukan kategori sangat tinggi sebesar 2400 dan skor total hasil angket sebesar 2070 maka dapat di persentasekan 86,25\% dari skor total hasil angket di bagi skor tertinggi di kali $100 \%$. Persentase 86,25\% tergolong pada kategori sangat kuat di antara 81\% - 100\% (Ridwan, 2011:41). Dari hasil ini diperoleh bahwa respon siswa terhadap keteladanan guru adalah positif, dapat di lihat dari angket yang 
menunjukan bahwa siswa setuju dengan keteladanan guru. Sesuai dengan teori yang di kemukakan oleh (Gustaf Ashirint, 2010 : 34 ).

Bagi seorang guru, menjadi teladan yang baik bagi anak didiknya adalah mutlak dan tidak bisa di tinggalkan karena itulah jalan satu-satunya untuk menciptakan anak didik yang unggul dan handal. Memang masa depan anak didik tergantung di pundak mereka masing-masing, namun sebagai guru merupakan kunci pembuka pintu ke masa depan, sebagai lentera yang menerangi jalan ke masa depan, adalah tongkat yang akan menuntun pada setiap titian menuju masa depan, dan lautan kasih sayang berlabuh dan berlayarnya perahu-perahu menuju dermaga keberhasilan.

\section{b. Perilaku disiplin peserta didik}

Perilaku disiplin peserta didik terutama di sekolah sangat penting sekali karena dengan perilaku disiplin akan membiasakan siswa untuk tertib dalam segala asfek. Baik di dalam kelas maupun di luar kelas.Berdasarkan hasil angket penelitian keteladanan guru di kelas V MI Negeri Maniskidul Kecamatan Jalaksana kabupaten Kuningan dengan jumlah 40 siswa di perolah menunjukan kategori sangat tinggi sebesar 2400 dan sekor total hasil angket sebesar 2057 maka dapat dipersentasekan $85,7 \%$ dari skor total hasil angket di bagi skor tertinggi di kali $100 \%$. Persentase sekor tersebut tergolong pada kategori sangat kuat di antara 81\% - 100\% (Ridwan, 2011:41).Dari hasil ini diperoleh bahwa respon siswa terhadap perilaku disiplin, menunjukan bahwa siswa setuju dengan perilaku disiplin.

\section{c. Pengaruh Keteladan Guru Terhadap Perilaku Disiplin Peserta Didik}

Konsep pembelajaran di sekolah haruslah di dukung dengan mengutamakan hal-hal yang nyata yang dapat di contoh serta berdampak baik kepada peserta didik. Dengan guru memberikan teladan yang baik maka dengan tanpa di sengaja akan menciptakan peserta didik yang berperilaku disiplin. 
Data yang di peroleh dari hasil penelitian, terdapat pengaruh yang signifikan antara keteladanan guru dengan perilaku disiplin peserta didik. Berdasarkan hasil penelitian dikoefisienkan dengan menggunakan standardizer coefficient nilai standardizer coefficient uji hipotesis nilai antara keteladanan guru dengan kedisiplinan peserta sebesar 6,482 serta signifikan 0,000. Untuk t tabesl dicari pada taraf signifikan 5\% dengan derajat kebebasan (df) n-k-1 atau 40-2-1 = 37. Dengan pengujian 2 sisi (signifikansi $=0,05$ ) hasil diperoleh untuk t tabel sebesar 1,71. Karena t hitung 6,482 lebih besar dari t tabel 1,71 maka Ho ditolak, sehingga yang menjadi jawaban dari hipotesis penelitian adalah $\mathrm{H}_{1}$ yang berarti ada pengaruh yang signifikan antara keteladanan guru dengan perilaku disiplin peserta didik

Hal ini sesuai dengan teori (Gustaf Asyirint 2010:34). Bagi seorang guru menjadi teladan bagi anak didiknya adalah mutlak dan tidak bisa di tinggalkan. Bahkan sebelum anda menjadi guru, keteladanan itu harus sudah tertanam dalam niat dan hati : Karena itulah jalan satu-satunya untuk bisa menciptakan anak didik yang unggul dan handal.

\section{F. Penutup}

\section{Kesimpulan}

Berdasarkan hasil analisis dan pembahasan yang telah dilakukan pada bab sebelumnya, maka peneliti megambil beberapa kesimpulan sebagai berikut:

a. Keteladanan Guru Madrasah Ibtidaiyah memiliki pengaruh yang sangat besar pada tumbuh kembang dan perilaku peserta didiknya. Dengan adanya keteladanan yang baik akan menciptakan generasi penerus bangsa yang baik pula.Pengaruh keteladanan guru ini terbukti menunjukan hasil yang cukup berjalan dengan baik didapat dari data yang diperoleh selama penelitian dan penyebaran angket yang 
dilakukan di MI Negeri Maniskidul Kecamatan Jalaksana Kabupaten Kuningan, yaitu perolehan skor rata- rata hasil angket untuk variabel $\mathrm{X}$ $86,25 \%$ skor tersebut terletak diantara setuju dengan sangat setuju.

b. Kedisiplinan peserta didik di MI Negeri Maniskidul Kecamatan Jalaksana Kabupaten Kuningan didapat dari data hasil angket untuk variabel $\mathrm{Y}$ yang diisi siswa sebesar $85,7 \%$ skor tersebut terletak diantara setuju dengan sangat setuju.

c. PengaruhKeteladanan guru Madrasah Ibtidaiyah terhadap perilaku disiplin peserta didikdi MI Negeri Maniskidul Kecamatan Jalaksana Kabupaten Kuninganberjalan dengan cukup baik dengan di peroleh data hasil data hasil penelitian dengan menggunakan uji regresi didapat harga R Square sebesar 0,525 atau 52,5\%.Sedangkan uji hipotesis diperoleh $\mathrm{t}_{\text {hitung }}=6,482$ lebih besar dari $\mathrm{t}_{\text {tabel }}=1,71$ pada taraf signifikan $\alpha=0,05$. Besarnya besarnya pengaruh keteladanan guru terhadap perilaku disiplin peserta didik sebesar $52,5 \%$

\section{Saran}

a. Di harapkan bagi guru agar bisa mempengaruhi sikap disiplin kepada para peserta didiknya, baik cara bertingkah laku, tutur kata maupun cara menyampaikan materi.

b. dan untuk peserta didik di harapkan mempunyai perilaku yang baik dan sikap di siplin sesuai dengan yang di contohkan oleh guru agar terciptanya suasana sekolah dan suasana belajar yang kondusif dan menyenangkan. 